\title{
Typification of two names in Mangifera (Anacardiaceae)
}

\author{
Kumar A. ${ }^{1 *} \&$ T. Chakrabarty ${ }^{2}$ \\ ${ }^{1}$ Central National Herbarium, Botanical Survey of India, Botanic Garden, Howrah, West Bengal - 711 103, India \\ 24, Botanical Garden Lane, Howrah, West Bengal - 711 103, India \\ *Email: anand_kum234@rediffmail.com
}

\begin{abstract}
Mangoes are considered one of the most important fruit crops in the tropics and subtropics especially in Asia. The nomenclature of two names in Mangifera, M. altissima Blanco and M. andamanica King are clarified here. The former is endemic to the Philippines and the latter is endemic to Andaman Island (India). The previous neotype designation of M. altissima is elucidated here and an epitype is designated for the precise application of the name. A lectotype is designated here for $M$. andamanica in the absence of a previously designated lectotype.
\end{abstract}

Keywords: Endemic, Fruit crop, Mangifera altissima, Mangifera andamanica, Nomenclature.

\section{Introduction}

The genus Mangifera L. is the most important fruit crop of the tropics and subtropics, particularly in Asia and considered as the "king of fruits" (Purseglove, 1972). Kostermans and Bompard (1993) recognized 69 species of which 11 species belong to subgenus Limus (Marchand) Kosterm., 47 species to subgenus Mangifera (Ding Hou) Kosterm. and 11 species remain in uncertain positions. The genus is natively distributed in Bangladesh, Bhutan, Brunei, Cambodia, Caroline Islands, China, India, Indonesia, Laos, Malaysia, Myanmar, Nepal, Papua New Guinea, Philippines, Singapore, Solomon Islands, Sri Lanka, Thailand and Vietnam with its major diversity with about 29 species in western Malesia, particularly in peninsular Malaysia, Borneo and Sumatra (Grierson, 1991; Press et al., 2000; Bompard, 2009).

Received: 29.08.2020; Revised \& Accepted: 26.06.2021 Published Online: 30.06 .2021
While working on the digitization of type specimens at CAL, we came across two names in the genus Mangifera of which M. altissima Blanco needs epitypification and $M$. andamanica King requires lectotypification. Mangifera altissima includes $M$. merrillii Mukherji, M. mucronulata Blume, M. parvifolia Boerl. \& Koord., M. rumphii Pierre and M. salomonensis C.T.White as synonyms and was earlier thought to be distributed in the Solomon islands, South New Britain, New Guinea, Moluccas, Philippines, Celebes and Lesser Sunda islands (Hou, 1978a). Subsequently, Kostermans and Bompard (1993) in their revision excluded all synonyms treated by Hou (1978a) and stated "Ding Hou included in this species several quite distinct other species", and therefore, the species is endemic to the Philippines. The unripe fruit is pickled, occasionally eaten fresh as a side dish with rice and also a minor source of timber (Kostermans \& Bompard, 1993). Mangifera andamanica is strictly endemic to Andaman Island and it has been never collected since the type collections (Ramana et al., 2017). However, Kanjilal et al. (1936) reported the species from the foot of the Mikar hills near Barpathar, Sibsagar. However, according to Kostermans and Bompard (1993), Mukherjee (1949) thought that it was not even a Mangifera. Hence, its occurrence in Assam remains doubtful.

The protologue and relevant literature for two names, Mangifera altissima and M. andamanica were studied. The type specimens from A, BM, CAL, GH, K, L, NY, P and US were also consulted for clarifying the nomenclature issue. The Shenzhen Code (Turland et al., 2018) is followed here to designate the types. 


\section{Typification}

Mangifera altissima Blanco, Fl. Filip. 181. 1837.

Neotype (first-step designated by Merrill, 1918; second-step designated by Kostermans \& Bompard, 1993): PHILIPPINES, "Illustrative specimen from Angat, Rizal Province, Luzon, December, 1914 (Merrill: Species Blancoanae No. 831)" (L [L0686906 digital image!]; isoneo A [A00049055 digital image!], CAL [CAL0000033690!], GH [GH00443918 digital image!], K [K001327111 digital image!], NY [NY00050782 digital image!], P [P02440608 digital image!], US [US00432690 digital image!]). Epitype (designated here): PHILIPPINES, Province of Rizal, Luzon, Jan.March, 1905, Ahern's collector 2442 (CAL [CAL0000033689!]).

Fig. 1

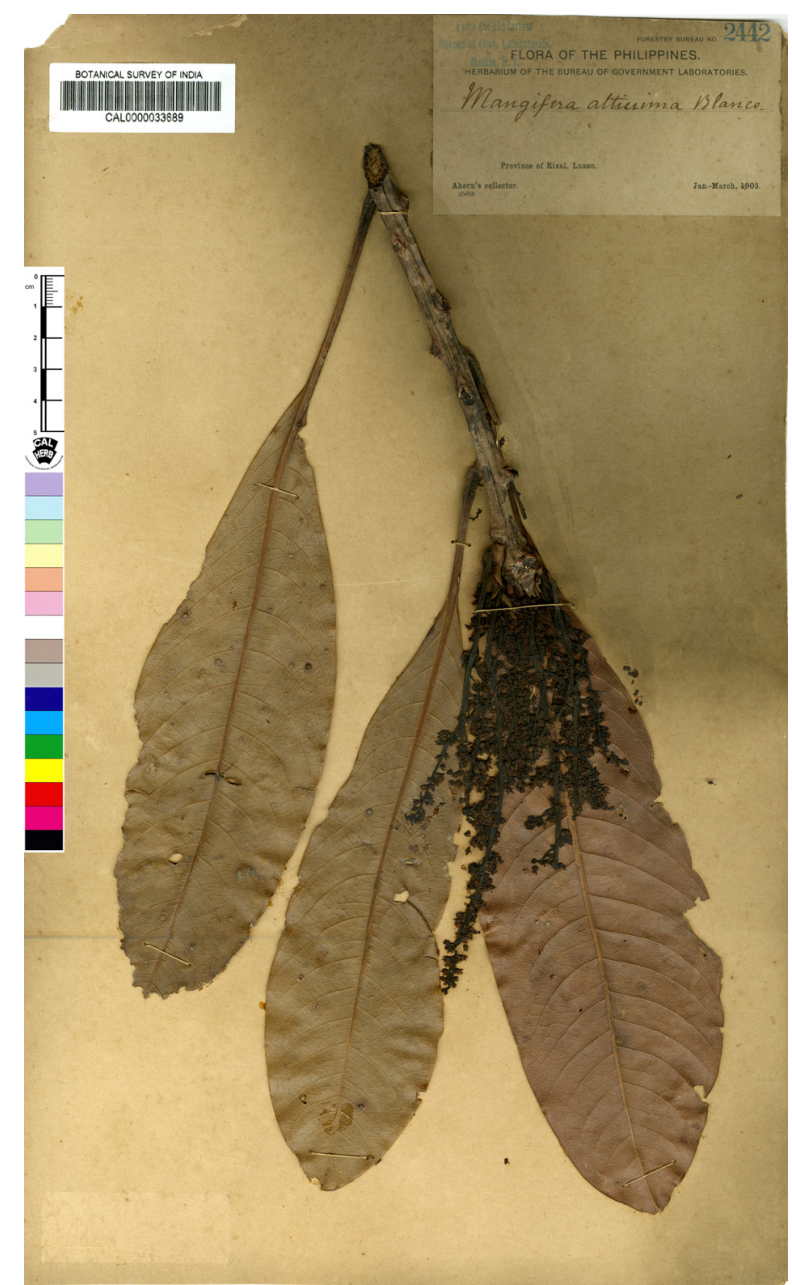

Fig. 1. Epitype of Mangifera altissima Blanco (CAL0000033689). (C) The Director, Botanical Survey of India. Reproduced with permission.
Notes: Blanco (1837) described Mangifera altissima and no materials of his collections survived (Merrill, 1918). Later, Merrill (1918) published "Species Blancoanae" and cited "Illustrative specimen from Angat, Rizal Province, Luzon, December, 1914 (Merrill: Species Blancoanae No. 831)" for Mangifera altissima. Merrill (1918, p. 36) also noted in the introductory chapter "specimens that to a large degree would take the place of Blanco's 'types' which were never preserved". The indication of 'types' denotes that he treated an "Illustrative specimen" as the equivalent of a neotype. Therefore, Merrill inadvertently designated "Species Blancoanae No. 831" as first-step neotype because specifying a herbarium was not necessary for type designation before 1990 under Art. 9.22 (Turland et al., 2018). Hou (1978b) mentioned the type in two herbaria (BO, L) and although before 1990 there was no need to mention any herbarium or more than one herbaria before 1990 as per Art. 9.22 (Turland et al., 2018). Hou's designation still cannot be accepted as an effective second-step neotypification as per Art. 9.17 (Turland et al., 2018) wherein citation of a single herbarium is compulsory. Later, Kostermans and Bompard (1993) cited "Mt Angat, Dec, fl, Merrill Spec. Blanco 831 (BO, K, L-holo, P)" and the citation of "L-holo" can be considered as effective second-step neotypification under Art. 9.17 (Turland et al., 2018). We could trace specimens at A, CAL, GH, K, L, NY, P and US. There are no specimens extant at $\mathrm{BO}$ (pers. comm., Drs Retnowati \& Arifiani). The second-step neotype specimen and all original materials are devoid of any flowers and fruits. As sterile specimens cannot help in the precise application of the name, therefore, we designate the flowering specimen CAL0000033689 as an epitype as per provisions of Art. 9.9 (Turland et al., 2018), because this specimen is bearing inflorescences and is collected from the same province ('Province of Rizal, Luzon') from where the neotype specimen was collected by Merrill.

Mangifera andamanica King, J. Asiat. Soc. Bengal, Pt. 2, Nat. Hist. 65(3): 470. 1896. Lectotype 
(designated here): INDIA, Andaman \& Nicobar Islands, Andamans, 1884, Dr. King's collector s.n. (CAL [CAL0000024405!]; isolecto BM [BM000884747 digital image!], CAL [CAL0000024412!, CAL0000024413!], K [K000695011 digital image!], P [P02440609 digital image!]). Syntypes: INDIA, Andaman \& Nicobar Islands, South Andaman Island, Hobdaypur, Hill jungle, 25.04.1891, Dr. King s.n. (CAL [CAL0000026152!, CAL0000026153!], K [K000695010 digital image!]).

Fig. 2

Notes: The protologue cites "Andaman Islands: King's collectors" (King, 1896). Kostermans and Bompard (1993) designated King's collector 39 (CAL) as lectotype and cited "Lecto-typus: $\mathrm{Mt}$ Harriett, June, fl., King's Coll. 39 (CAL)”. After a

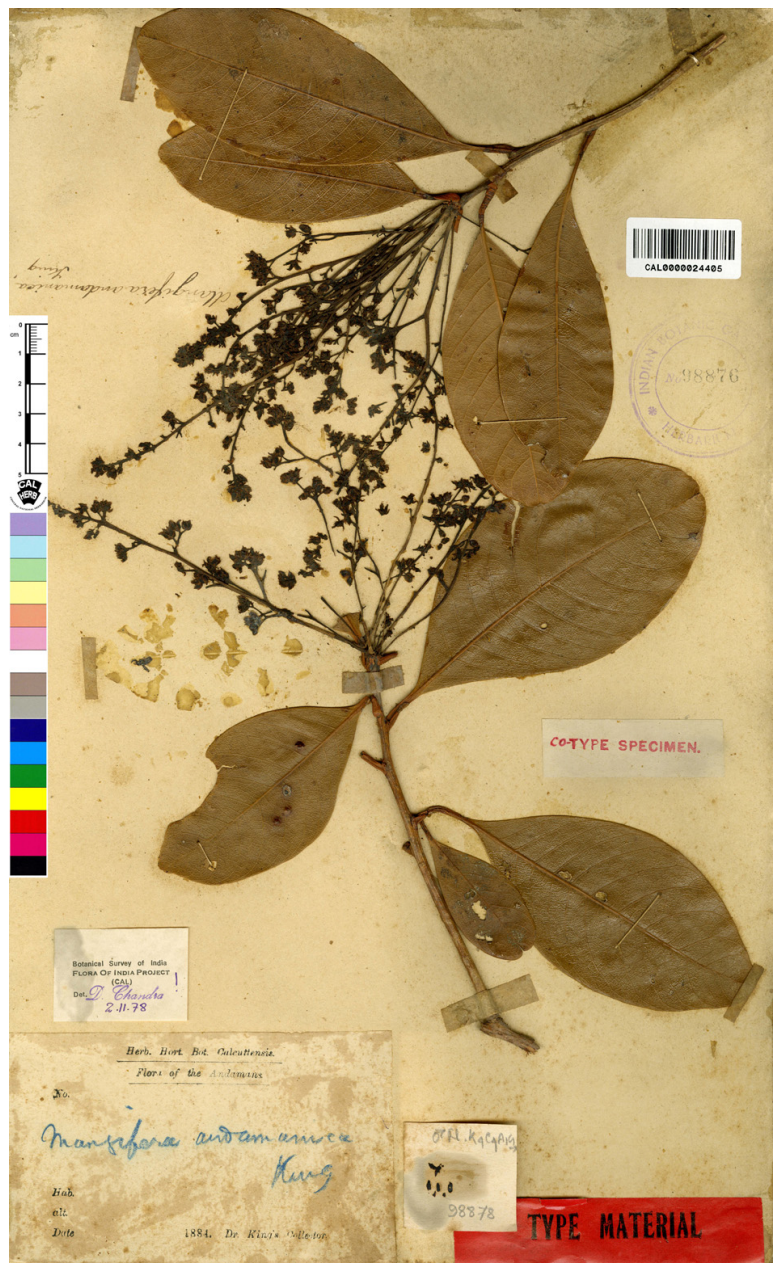

Fig. 2. Lectotype of Mangifera andamanica King (CAL0000024405). (C) The Director, Botanical Survey of India. Reproduced with permission. thorough search of CAL, we could not trace flowering specimen ('June') of King's collector 39 from Mount Harriet. We could trace five specimens at CAL of $M$. andamanica of which three from the Andamans were without precise locality and two specimens were collected from Hobdaypur, South Andaman Island. In addition, there were two specimens found at K of which one (K000695011, digital image!) is without precise locality and the second is from Hobdaypur (K000695010, digital image!). Moreover, no collection number is mentioned on any cited specimens. Therefore, a new lectotype designation is needed in the absence of the previously designated lectotype King's collector 39 from Mount Harriet. Moreover, all three specimens from Hobdaypur were collected by Dr. King himself in fruiting and the remaining specimens without precise locality were collected in flowering by Dr. King's collector. The best preserved flowering specimen CAL0000024405 is designated here as lectotype because the species is recognized by flowering material with 4-merous flowers and well develop disc (Kostermans \& Bompard, 1993).

\section{Acknowledgements}

The authors are thankful to the Director, Botanical Survey of India, Kolkata and Head of Office, Central National Herbarium for the facilities. We are also thankful to Dr Marie Briggs (K) for sending the image of Mangifera altissima Blanco; Drs Atik Retnowati (BO) and Deby Arifiani (BO) for personally communicating the non-availability of type specimen of Mangifera altissima Blanco at BO; anonymous reviewers and editor for improving the quality of the manuscript.

\section{Literature Cited}

BLANCO F.M. 1837. Flora de Filipinas. En la Imprenta de Sto. Thomas por D. Candido Lopez, Manila.

BOMPARD J.M. 2009. Taxonomy and systematics. In: LITZ R.E. (ed.), The Mango, $2^{\text {nd }}$ Edition: Botany, Production and Uses. CAB International, Wallingford, UK. pp. 19-41. 
GRIERSON A.J.C. 1991. Anacardiaceae. In: GRIERSON A.J.C. \& D.G. Long (eds.), Flora of Bhutan. Volume 2, Part 1. Royal Botanic Garden, Edinburgh. pp. 54-93.

HOU D. 1978a. Mangifera. In: VAN STEENIS C.G.G.J. (ed.), Flora Malesiana. Series I, Volume 8. National Herbarium of the Netherlands, Leiden, Netherlands. pp. 423-440.

HOU D. 1978b. Florae Malesianae Praecursores LVI. Anacardiaceae. Blumea 24: 1-41.

KANJILAL U.N., KANJILAL P.C., DAS A. \& C. PURKAYASTHA 1936. Flora of Assam: Linaceae to Moringaceae. Volume. 1, Part 2. Govt. of Assam, Shillong.

KING G. 1896. Materials for a Flora of the Malayan Peninsula. Journal of the Asiatic Society of Bengal, Part 2, Natural History 65: 339-516.

KOSTERMANS A.J.G.H. \& J.M. BOMPARD 1993. The Mangoes: Their Botany, Nomenclature, Horticulture and Utilization. Academic Press, London, UK.

MERRILL E.D. 1918. Species Blancoanae. Bureau of Printing, Manila.
MUKHERJEE S.K. 1949. A monograph on the genus Mangifera. Lloydia. 12: 73-136.

PRESS J.R., SHRESTHA K.K. \& D.A. SUTTON 2000. Annotated Checklist of the Flowering Plants of Nepal. The Natural History Museum, London.

PURSEGLOVE J.W. 1972. Mangoes west of India. Acta Horticulture 24: 107-174.

RAMANA M.V., VENU P. \& M. SANJAPPA 2017. Implications of mistaken identities in conservation of wild mangoes. Current Science 112: 1107-1108. https:// doi.org/10.18520/CS/V112/I06/1107-1108

TURLAND N.J., WIERSEMA J.H., BARRIE F.R., GREUTER W., HAWKSWORTH D.L., HERENDEEN P.S., KNAPP S., KUSBER W.-H., LI D.-Z., MARHOLD K., MAY T.W., MCNEILL J., MONRO A.M., PRADO J., PRICE M.J. \& G.F. SMITH (eds.) 2018. International Code of Nomenclature for algae, fungi, and plants (Shenzhen Code) adopted by the Nineteenth International Botanical Congress Shenzhen, China, July 2017. Regnum Vegetabile 159. Volume 38 Koeltz Botanical Books, Glashütten. https://doi.org/ 10.12705/Code. 2018 